\title{
Participation in vocational training among nurses and midwives during specialization
}

\section{Udział w szkoleniach zawodowych pielęgniarek i położnych specjalizujących się}

\author{
Aleksander A. Zarzeka ${ }^{1, C, D}$, Jarosława Belowska ${ }^{1, B, E}$, Mariusz Panczyk1, ${ }^{1, C}$, , Halina Żmuda-Trzebiatowska ${ }^{2, A, E}$, \\ Barbara Kot-Doniec ${ }^{3, A, B}$, Joanna Gotlib ${ }^{1, A, E, F}$ \\ ${ }^{1}$ Division of Teaching and Outcomes of Education, Faculty of Health Science, Medical University of Warsaw, Poland \\ ${ }^{2}$ Postgraduate Training Centre for Nurses and Midwives, Division of Clinical Nursing, Faculty of Health Science, Medical University of Warsaw, Poland \\ ${ }^{3}$ Postgraduate Training Centre for Nurses and Midwives, Warsaw, Poland \\ A - research concept and design; $\mathrm{B}$ - collection and/or assembly of data; $\mathrm{C}$ - data analysis and interpretation; \\ $D$ - writing the article; $E$ - critical revision of the article; $F$ - final approval of article
}

Address for correspondence

Aleksander A. Zarzeka

E-mail: aleksander.zarzeka@wum.edu.pl

Conflict of interests

None declared

Received on June 22, 2016

Revised on August 7, 2016

Accepted on 0ctober 25, 2016

DOI

10.17219/pzp/66333

Copyright

○ 2017 by Wroclaw Medical University

This is an article distributed under the terms of the

Creative Commons Attribution Non-Commercial License

(http://creativecommons.org/licenses/by-nc-nd/4.0/)

\begin{abstract}
Background. Permanent professional development is a right and obligation of all nurses and midwives (N\&M). It is a result of the constant changes in medical and nursing standards as well as the provisions of the law regulating the profession.

Objectives. The aim of the study was to diagnose the preferences and problems of N\&M during specialization concerning postgraduate professional courses.

Material and methods. The study group consisted of 932 N\&M who took part in a specialization exam in Warsaw (autumn exam session of 2014). Women constituted $91 \%$ of all respondents. The mean age of the study participants was 48 years (min. 26, max. 64, SD 6.71, median 42, mode 40). The instrument was an original questionnaire. The authors performed a quantitative analysis of the data, assessing the frequency of answers and identifying structural indicators for these answers.
\end{abstract}

Results. Most N\&M (66.6\%) during specialization take part in postgraduate professional courses 1-3 times a year. There are more internal (38.2\%) than external (28.4\%) courses. Courses are most often financed by an employer (24.6\%) or by the nurses themselves (24.1\%) and $8.3 \%$ of the courses have more than one source of financing. Forty per cent of the study participants had experienced problems (mostly financial) with taking part in vocational courses. Only $14 \%$ of the respondents had ever taken part in an e-learning course.

Conclusions. Most of the difficulties of the N\&M in taking part in postgraduate professional courses resulted from objective reasons and thus an introduction of the broad, systemic changes in access to postgraduate courses is worth considering. An introduction of modern technologies (online courses) to the continuing education of N\&M could improve access to postgraduate courses since time barriers would be overcome and the cost of training would be reduced. There is a need to continue research on the preparation of N\&M to take part in e-learning or blended learning courses.

Key words: nurses and midwifes, professional courses, e-learning, financing of courses 


\section{Streszczenie}

Wprowadzenie. Stałe zwiększanie swoich kwalifikacji należy do praw i obowiązków każdej pielęgniarki i położnej. Wynika to zarówno z wymagań szybko zmieniających się standardów wiedzy medycznej, jak i przepisów prawa regulującego wykonywanie tego zawodu.

Cel pracy. Rozpoznanie preferencji i problemów pielęgniarek i położnych specjalizujących się w zakresie udziału w szkoleniach zawodowych.

Materiał i metody. Badania przeprowadzono w grupie pielęgniarek i położnych przystępujących do egzaminów państwowych organizowanych przez Centrum Kszzałcenia Podyplomowego Pielęgniareki Położnych w sesji jesiennej 2014 r. W badaniu łącznie udział wzięły 932 osoby. Większośś stanowiły kobiety - 848 (91\%), a mężczyzn było 28 (3\%), 56 osób (6\%) nie udzieliło odpowiedzi na pytanie o płeć. Średnia wieku badanej grupy wyniosła 42 lata (min. - 26, maks. - 64, SD =6,71, mediana - 42, modalna - 40). Do badań wykorzystano autorski kwestionariusz. Zastosowano metodę analizy llościowej przez ocenę częstości i wyznaczenie wskaźników struktury dla otrzymanych odpowiedzi.

Wyniki. Pielęgniarki i położne specjalizujące się uczestniczą w szkoleniach zawodowych najzzęściej 1-3 razy w roku (66,6\%). Przeważają szkolenia wewnętrzne (38,2\%) nad zewnętrznymi (28,4\%). Szzolenia zwykle są finansowane w 100\% przez zakład pracy (24,6\%) lub przez pielęgniarki (24,1\%); czasem zdarza się również finansowanie mieszane - 8,3\%. Aż 40\% badanych wskazało na trudności związane z udziałem w szkoleniach zawodowych. Wśród nich największa grupa spotkała się z barierami finansowymi. Jedynie $14 \%$ badanych kiedykolwiek korzystało ze szkolenia w formie e-learningu.

Wnioski. Trudności pielęgniarek i położnych z uczestnictwem w szkoleniach zawodowych wynikały z czynników obiektywnych, dlatego też należy rozważyć wprowadzenie zmian systemowych w dostępie do szkoleń w tej grupie zawodowej. Wykorzystanie nowoczesnych technologii informatycznych (np. e-learningu) w kszztałceniu pielęgniarek i położnych mogłoby zwiększyć dostępność do szkoleń w tej grupie zawodowej ze względu na zniesienie barier czasowych oraz obniżenie koszzów. Należy kontynuować badania z zakresu analizy przygotowania pielęgniarek i położnych do udziału oraz ich zainteresowania szkoleniami z zastosowaniem nowoczesnych technologii informatycznych.

Słowa kluczowe: pielęgniarki i położne, szkolenie zawodowe, e-learning, finansowanie szkoleń

\section{Introduction}

In Poland, there are as many as 312,883 practicing nurses and midwives, and women constitute a vast majority of the total (98.4\%). There are 298,486 female and male nurses and 34,387 female and male midwives. ${ }^{1}$ These professional groups are much more numerous than the group of doctors (159,285 persons). ${ }^{2}$ Improvement of the competence of such a numerous group is a serious functional and organizational challenge for the Polish health care system.

Permanent professional development is a right and obligation of every nurse and midwife. It is a result of constantly changing medical and nursing standards as well as the provisions of the law regulating these professions (Article 61, paragraph 1 of the Nurses and Midwives Act, hereinafter referred to as the Act). ${ }^{3}$

The Act sets forth that participation in vocational training is both a right and duty of every nurse and midwife, but it also specifies the types and aims of such courses. Article 66 says that the postgraduate training of nurses and midwives includes: specialized training ("specialization"), qualification courses, specialization courses, and retraining courses.

The aim of specialization is that "a nurse or midwife gains specialized knowledge and skills in a particular area of nursing or area applicable to health protection" (Article 67 of the Act). In Poland, 18,654 nurses and midwives have a specialization, constituting $6 \%$ of all practicing nurses and midwives. Preventive nursing and surgical nursing are among the most popular specializations for nurses. The largest number of midwives are specialists in obstetric nursing and anesthetic and intensive care nursing. Both professional groups are very interested in specialization in organization and management.

A qualification course is of smaller scale than specialization because it aims at providing nurses and midwives with the knowledge and skills necessary to provide particular health services in a given area. In Poland, 56,905 nurses and midwives have graduated from qualification courses, constituting $18 \%$ of all practicing nurses and midwives. The largest number of nurses and midwives acquired qualifications in family nursing. Nurses are also interested in courses devoted to anesthetic and intensive care nursing. ${ }^{4}$

Article 72, paragraph 1 of the Act says that "the aim of a specialization course is to provide nurses and midwives with knowledge and skills necessary to perform specific professional activities when providing nursing, preventive, diagnostic, medical or rehabilitation services". Retraining courses are the most general, thus they may focus on efficient methods for informing patients as well as on the law in health protection and rules concerning civil, criminal and professional liability.

According to information provided by the Ministry of Health, so far over 45,000 nurses and midwives have participated in professional courses conducted under the Human Capital Operational Programme financed by the European Social Fund for 2008-2015. This data does not include specialized training that was not financed by this specific program. However, bridging courses were taken into account. ${ }^{5}$ 
Vocational training may be divided into internal (organized by employers) and external, which often determines their financing. Internal training is, to a large extent, "free of charge" for participants; however, they do not always relate to the areas of interest of particular nurses and midwives but more often they correspond to the ones "needed" by a sponsor.

Many nurses and midwives are willing to improve their knowledge and skills in many areas, but they face numerous obstacles. ${ }^{6}$ These difficulties are of a financial as well as of an administrative, personal, and professional nature. Current technical capabilities allow for a modification of the forms of professional courses. A lot of them may be conducted in the form of so-called e-learning, which makes the entire course more flexible and less expensive.

The aim of the study was to diagnose the preferences and problems of nurses and midwives during specialization concerning post-graduate professional courses.

\section{Materials and methods}

The study group consisted of nurses and midwives taking a specialization exam organized by the Postgraduate Training Center for Nurses and Midwives in Warsaw (autumn exam session of 2014).

Nine hundred thirty-two persons participated in the study, including 848 women (91\% of the total) and 28 men (3\% of the total); 56 persons $(6 \%)$ did not provide information about gender. The mean age of the group amounted to 42 years (min. 26, max. 64, SD 6.71, median 42, mode 40).

Married women constituted the largest subgroup (626 persons, $67 \%$ of all) regarding marital status, and there were also 101 single women (11\%), 24 divorced women (2.6\%), and 8 widows. As far as men were concerned, there were 49 bachelors (5\%) and 9 men were married (1\%). One hundred five persons (11\%) did not respond to the question about their marital status.

Persons living in towns up to 100,000 citizens constituted the largest subgroup (249 persons, 27\%) regarding population centers among the study participants. Two hundred thirty persons (25\%) lived in cities between 100,000 and 500,000 citizens, 218 respondents (23\%) lived in villages, and 176 study participants (19\%) lived in cities over 500,000 citizens. Fifty-nine persons (6\%) provided no answer to that question.

The largest subgroup regarding level of education, constituting 301 persons (32\%), had secondary medical education, 267 respondents (29\%) had a Master's degree and 260 study participants (28\%) had a Bachelor's degree. Two persons $(0.2 \%)$ had a doctoral degree. One respondent $(0.1 \%)$ had a degree in engineering and one person $(0.1 \%)$ was in the middle of a Bachelor's degree program. Eleven per cent of the respondents (101 persons) did not provide any information on their education level.
As far as postgraduate training was concerned, 194 study participants (21\%) had graduated from a qualification course, 69 persons (7\%) had completed a specialization course, 59 respondents $(6 \%)$ had a specialization (specialized training), and 19 persons (2\%) had graduated from a retraining course. Five hundred ninety one respondents (64\%) had not completed any such courses or did not provide any information on the scope of postgraduate courses they had participated in.

An original questionnaire constituted a research tool in the study. The authors performed a quantitative analysis of the data assessing the frequency of answers and identifying structural indicators for these answers. Cronbach's alpha coefficient was established to assess compatibility in selecting course subjects related to medical law.

\section{Results}

Two-thirds of the nurses participated in vocational courses once, twice, or three times a year. Only a small percentage of the respondents had not taken part in such courses at all and not many more participated in training more often than 3 times a year. Every $5^{\text {th }}$ respondent chose the answer "hard to say" (Table 1).

Every $6^{\text {th }}$ study participant said that he or she had taken part in a skills improvement course. Despite a very small percentage of negative answers, there was a large number of nurses and midwives who answered "difficult to say" (Table 2).

The nurses and midwives had participated in courses organized by their employers as well as in so-called "external" training. A majority of the respondents indicated internal courses. Three in 10 study participants did not provide any answer to this question (Table 3).

Study participants were also asked about the sources of financing. Most courses had been financed by employers, but nearly as many respondents had had to cover the costs themselves. A small percentage of training had been co-financed by employers and employees. Almost 1 in 10 respondents had participated in courses financed by EU funds. The following forms of financing were also mentioned (in descending order): Chamber of Nurses and Midwives, Ministry of Health, and a company hosting the course. The vast majority of nurses and midwives, again, did not provide a specific answer to the question, indicating "difficult to say" or "not applicable" options, or not providing any answer at all (Table 4).

The nurses and midwives were also asked whether their employer evaluated their needs as far as the organization and performance of training were concerned. More than half of the respondents replied positively. Every $4^{\text {th }}$ person said that no data concerning the training-related needs of the employees was collected or analyzed at their workplace (Table 5). 
Table 1. Frequency of participating in postgraduate courses

\begin{tabular}{|l|c|c|}
\hline $\begin{array}{l}\text { How often do you take part } \\
\text { in vocational courses? }\end{array}$ & $\begin{array}{c}\text { Number } \\
\text { of persons }\end{array}$ & Percentage \\
\hline $\begin{array}{l}\text { I do not participate in vocational } \\
\text { trainings at all }\end{array}$ & 41 & 4.4 \\
One to three times a year & 621 & 66.6 \\
Four to six times a year & 44 & 4.7 \\
More than six times a year & 23 & 2.5 \\
Difficult to say & 188 & 20.2 \\
No answer & 15 & 1.6 \\
\hline
\end{tabular}

Table 2. Participation in courses over the past year

\begin{tabular}{|l|c|c|}
\hline $\begin{array}{l}\text { Have you participated in skills } \\
\text { improvement courses over the past } \\
\text { year? }\end{array}$ & $\begin{array}{c}\text { Number } \\
\text { of persons }\end{array}$ & Percentage \\
\hline Yes & 158 & 17.0 \\
No & 2 & 0.2 \\
Difficult to say & 765 & 82.1 \\
No answer & 7 & 0.8 \\
\hline
\end{tabular}

Table 3. Form of vocational training

\begin{tabular}{|l|c|c|}
$\begin{array}{l}\text { Please indicate the form of vocational } \\
\text { trainings you have participated in over } \\
\text { the past year }\end{array}$ & $\begin{array}{c}\text { Number } \\
\text { of persons }\end{array}$ & Percentage \\
\hline $\begin{array}{l}\text { Internal, organised by your employer } \\
\text { External }\end{array}$ & 356 & 38.2 \\
Difficult to say & 265 & 28.4 \\
Other & 22 & 2.4 \\
No answer & 9 & 1.0 \\
\hline
\end{tabular}

Table 4. Sources of financing

\begin{tabular}{|l|c|c|}
\hline What were the sources of financing? & $\begin{array}{c}\text { Number } \\
\text { of persons }\end{array}$ & Percentage \\
\hline Fully financed by employer & 229 & 24.6 \\
Partly financed by employer & 77 & 8.3 \\
Fully financed by myself & 225 & 24.1 \\
Financed/co-financed by EU funds & 89 & 9.5 \\
Other & 22 & 2.4 \\
Difficult to say & 24 & 2.6 \\
Does not concern & 70 & 7.5 \\
No answer & 196 & 21.0 \\
\hline
\end{tabular}

The present analysis also concerned the forms of courses, part of which can be conducted in the form of elearning. A part of the respondents had already experienced this form of professional development. However, the vast majority of nurses and midwives had still never participated in an e-learning course (Table 6).

Many nurses and midwives (40\%) had experienced difficulties when they wanted to take part in vocational training. However, more than half of the study participants reported not having any of such problems (Table 7).
Table 5. Diagnosis of training-related needs at workplace

\begin{tabular}{|l|c|c|}
$\begin{array}{l}\text { Does your employer collect and } \\
\text { analyse information on training-related } \\
\text { needs of the staff? }\end{array}$ & $\begin{array}{c}\text { Number } \\
\text { of persons }\end{array}$ & Percentage \\
\hline Yes & 571 & 61.3 \\
No & 235 & 25.2 \\
I do not know & 109 & 11.7 \\
No answer & 17 & 1.8 \\
\hline
\end{tabular}

Table 6. Experience in e-learning courses

\begin{tabular}{|l|c|c|}
$\begin{array}{l}\text { Have you ever participated } \\
\text { in any form of e-learning } \\
\text { courses? }\end{array}$ & $\begin{array}{c}\text { Number } \\
\text { of persons }\end{array}$ & Percentage \\
\hline Yes & 133 & 14.3 \\
No & 695 & 74.6 \\
I do not know & 64 & 6.9 \\
No answer & 40 & 4.3 \\
\hline
\end{tabular}

Financial barriers were mentioned by the largest number of study participants as the most common difficulties they had encountered. These were followed by a bad work environment, impossibility of finding a replacement and insufficient training dates. Family considerations were mentioned by a very small percentage of the respondents (Table 8).

\section{Discussion}

The issue of vocational training has been widely discussed in the Polish literature. ${ }^{6-9,11,12}$ The analyses mostly focused on motivation for undertaking various forms of further education, as well as what kind of barriers nurses and midwives face on their way to improving their skills. However, the authors saw the need to conduct a similar study among nurses and midwives during specialization.

Lifelong learning constitutes an integral part of the professional career of a nurse or midwife. ${ }^{6}$ This is of particular importance in the present age of rapidly-developing medicine and health sciences. It has been proven that the right and duty of continuing education is exercised in both professions. The fact that only a small percentage of the respondents reported that they had not participated in vocational courses leads to the conclusion that nurses and midwives improve their competences in a satisfactory manner. This does not mean, however, that the situation here is ideal. The present study results agree with those obtained by Tomaszewska et al. ${ }^{7}$ and Cison-Apanasewicz et al. ${ }^{9}$ The latter demonstrated that over $90 \%$ of respondents saw the need to take part in postgraduate training.

What is surprising is the fact that a large proportion of the respondents did not provide any specific answer to the question about participation in any course over the 
Table 7. Difficulties with respect to participation in vocational training

\begin{tabular}{|l|c|c|}
$\begin{array}{l}\text { Have you ever experienced any } \\
\text { difficulties (e.g. professional, personal) } \\
\text { when you wanted to take part } \\
\text { in a course? }\end{array}$ & $\begin{array}{c}\text { Number } \\
\text { of persons }\end{array}$ & Percentage \\
\hline Yes & 376 & 40.3 \\
No & 476 & 51.1 \\
Difficult to say & 53 & 5.7 \\
No answer & 27 & 2.9 \\
\hline
\end{tabular}

past year, and chose the "difficult to say" option. This may mean that they did not understand the question, did not remember or did not attach importance to this issue. All seem to be worrying. An analysis of the question may also suggest that, although the respondents had participated in a course, they were not sure whether it had improved their professional skills. This, in turn, would reflect very badly on the training providers and instructors. A full understanding of the issue requires a more indepth analysis.

The financing of courses seems to be an interesting aspect. The present study showed that a similar number of courses were financed by employers and the participants themselves. These results are similar to those obtained by Mytkowski et al., who found that half of departmental nurses had had to cover the costs of at least one training themselves and only in the case of $1 / 3$ of the total courses had the training been fully financed by the employers. The results among ward nurses were more optimistic, since as many as $40 \%$ of the nurses had received full financing and $1 / 4$ had received co-financing and only $1 / 3$ had had to cover all costs themselves. ${ }^{8}$ What is surprising here is the fact that the co-financing of courses by employers with the contribution of the employee was not very popular. In an age of increased labor costs and development of the training sector, such a solution seems to be reasonable.

A relatively small group of nurses and midwives apply for financing or co-financing of courses with UE funds. The attractiveness of a course certainly depends on its cost. This is why, among others, specialization courses were more popular among the study participants than, e.g., specialized training. ${ }^{9}$

Data on the training-related needs of employees always needs to be diagnosed and analyzed by employers. This study showed that this was not the case in many situations. What is more, the report mentioned above showed that the management of health care entities believed that the training-related needs of the staff were satisfied to a much greater extent than it was according to the staff themselves, nurses and midwives included. ${ }^{8}$

A lot of vocational training may be conducted with the use of modern techniques such as e-learning. ${ }^{10}$ E-learning may be used for teaching mostly non-clinical issues such as law in medicine and organization and management,
Table 8. Types of difficulties with respect to participation in vocational training

\begin{tabular}{|lcc|}
\hline $\begin{array}{l}\text { Please indicate difficulties you have } \\
\text { experienced }\end{array}$ & $\begin{array}{c}\text { Number } \\
\text { of persons }\end{array}$ & Percentage \\
\hline Financial barriers & 102 & 10.9 \\
$\begin{array}{l}\text { Insufficient dates of available courses } \\
\text { Lack of replacement }\end{array}$ & 43 & 4.6 \\
$\begin{array}{l}\text { Distance between the place of training } \\
\text { and the place of residence is too big }\end{array}$ & 18 & 6.3 \\
$\begin{array}{l}\text { Obligations arising from the need to care } \\
\text { for child/children or other persons }\end{array}$ & 20 & 1.9 \\
$\begin{array}{l}\text { No available trainings in a particular } \\
\text { discipline }\end{array}$ & 13 & 2.1 \\
$\begin{array}{l}\text { Bad work environment, lack of approval } \\
\text { for persons developing their skills }\end{array}$ & 73 & 7.4 \\
$\begin{array}{l}\text { Other } \\
\text { Does not concern }\end{array}$ & 217 & 23.3 \\
No answer & 385 & 41.3 \\
\hline
\end{tabular}

but also strictly medical subjects when using modern audiovisual techniques. ${ }^{10}$ However, this study demonstrated that a very small number of nurses and midwives had participated in this kind of course. This means that there is potential for the development of e-learning in postgraduate training of medical personnel.

The difficulties faced by nurses and midwives who are willing to improve their competences has been broadly discussed in the literature. A study by Nowicki et al. conducted among a group of nurses specializing in emergency nursing showed that a lack of financial resources (71\%), lack of time (56\%) and lack of approval from superiors were among the most frequent barriers in this respect. ${ }^{11}$ On the other hand, Kobos et al. pointed to the fact that particularly the lack of clear rules concerning training leave (76\%) and financial support from employers (74\%) makes it difficult to decide on training, and physical and mental exhaustion after a day at work (85\%) makes the course itself unpleasant. ${ }^{12}$

The present study demonstrated that nearly half of the nurses and midwives faced difficulties associated with participation in skill improvement courses. The authors also tried to identify barriers to participation in training. As was mentioned above, financial barriers are the most common type, followed by those on the part of the employer: unpleasant atmosphere at work, lack of understanding, no replacement at work during the course. These results correspond to the ones obtained by Tomaszewska et al. and Cioson-Apanasewicz et al. The latter added to that the lack of self-motivation of the personnel. ${ }^{6,9}$

The selection of the study participants limited to nurses and midwives during specialization was a major limitation of the study. Therefore a further study extended to issues related to the content and preferred forms of postgraduate training among other groups of nurses seems to be necessary. 


\section{Conclusions}

Among the study group, most of difficulties in taking part in postgraduate professional courses resulted from objective reasons and thus, an introduction of broad systemic changes in access to postgraduate courses is worth considering.

The introduction of modern technologies (online courses) to the continuing education of nurses and midwives could improve access to postgraduate courses since time barriers would be overcome and the cost of training would be reduced.

There is a need to continue research on the preparation of nurses and midwives to take part in e-learning or blended learning courses as well as on their interest in using modern technologies.

\section{References}

1. Oficjalne dane statystyczne Naczelnej Izby Pielęgniarek i Położnych w zakresie liczby zarejestrowanych i wykonujących zawód pielęgniarki i położnej na dzień 31.12.2012 r. http://www.nipip.pl/ index.php/samorzad/stat/1919-liczba-pielegniarek-i-poloznychzarejestrowanych-i-zatrudnionych (data dostępu: 9.11.2014).

2. Centralny Rejestr Lekarzy i Lekarzy Dentystów. Dane na dzień 31.12.2012 r. http://www.nil.org.pl/__data/assets/pdf_file/0019/ 73342/Zestawienie-nr-01.pdf (data dostępu: 9.11.2014).

3. Ustawa z dnia 15 lipca 2011 r. o zawodach pielęgniarki i położnej (Dz.U. z 2011 r. Nr 147, Poz. 1039).

4. Oficjalne dane statystyczne Naczelnej Izby Pielęgniarek i Położnych w zakresie kształcenia podyplomowego pielęgniarek i położnych na dzień 31.12.2012 r.http://www.nipip.pl/index.php/samorzad/stat/1926wyksztalcenie-pielegniarek-i-poloznych (data dostępu: 9.11.2014).

5. Oficjalne dane Ministerstwa Zdrowia za portalem rynekzdrowia.pl http://www.rynekzdrowia.pl/Nauka/MZ-dzieki-srodkom-z-UE-polskie-pielegniarki-podniosly-kwalifikacje-statystyka,143550,9.html (data dostępu: 9.11.2014).

6. Tomaszewska M, Cieśla D, Czerniak J, Dykowska G. Możliwości doskonalenia zawodowego pielęgniarek - potrzeby a rzeczywistość. Probl Pielęg. 2008; 16(1,2): 40-47.

7. Palczewska A. Analiza kształcenia podyplomowego pielęgniarek i położnych na północno-wschodnim Mazowszu. Probl Pielęg. 2008; 16(3): 285-292.

8. Mytkowski D, Komosa M, Niedzielska E. Analiza potrzeb szkoleniowych personelu medycznego oraz pracowników wykonujących zawody niemedyczne $w$ ramach systemu opieki zdrowotnej w Polsce. IBC Group Central Europe Holding S.A. na zlecenie Ministerstwa Zdrowia, Warszawa 2011. https://www.ewaluacja.gov.pl/ Wyniki/Documents/6_125.pdf (data dostępu: 10.11.2014).

9. Cisoń-Apanasewicz U, Gaweł G, Ogonowska D, Potok H. Opinie pielęgniarek na temat kształcenia podyplomowego. Probl Pielęg. 2009; 17(1): 33-37.

10. Kononowicz A, Pyrczak W, Roterman-Konieczna I. E-learning in medicine. Probl Hig Epidemiol. 2006; 86(4).

11. Nowicki G, Chilimoniuk B, Goniewicz M, Górecki M. Możliwości i bariery rozwoju zawodowego pielęgniarek w opinii uczestników specjalizacji $w$ dziedzinie pielęgniarstwa ratunkowego. Probl Pielęg. 2012; 20(4): 473-479.

12. Kobos E, Leńczuk Gruba A, Idzik A, Sienkiewicz Z. Rola zakładu pracy $w$ dokształceniu i doskonaleniu zawodowym w kontekście barier edukacyjnych dostrzeganych przez pielęgniarki. Probl Pielęg. 2010; 18(2): 134-138. 